\title{
Measurement Uncertainty of Adsorption Testing of Desiccant Materials
}

Carl E. Bingham

Ahmad A. Pesaran

December 1988

Prepared for the 1989 ASME

Solar Energy Division Conference

San Diego, Califomia

April 2-4, 1989

Prepared under Task No. SB811141

Solar Energy Research Institute

A Division of Midwest Research Institute

1617 Cole Boulevard

Golden, Colorado 80401-3393

Prepared for the

U.S. Department of Energy

Contract No. DE-AC02-83CH10093 


\section{NOTICE}

This report was prepared as an account of work sponsored by an agency of the United States government. Neither the United States government nor any agency thereof, nor any of their employees, makes any warranty, express or implied, or assumes any legal liability or responsibility for the accuracy, completeness, or usefulness of any information, apparatus, product, or process disclosed, or represents that its use would not infringe privately owned rights. Reference herein to any specific commercial product, process, or service by trade name, trademark, manufacturer, or otherwise does not necessarily constitute or imply its endorsement, recommendation, or favoring by the United States government or any agency thereof. The views and opinions of authors expressed herein do not necessarily state or reflect those of the United States government or any agency thereof.

Printed in the United States of America

Available from:

National Technical Information Service

U.S. Department of Commerce

5285 Port Royal Road

Springfield, VA 22161

Price: Microfiche A01

Printed Copy A02

Codes are used for pricing all publications. The code is determined by the number of pages in the publication. Information pertaining to the pricing codes can be found in the current issue of the following publications which are generally available in most libraries: Energy Research Abstracts (ERA); Government Reports Announcements and Index (GRA and I); Scientific and Technical Abstract Reports (STAR); and publication NTIS-PR-360 available from NTIS at the above address. 


\section{MEASUREMENT UNCERTAINTY OF ADSORPTION TESTING}

OF DESICCANT MATERIALS

CARL E. BINGHAM

AHMAD A. PESARAN

SOLAR ENERGY RESEARCH INSTITUTE

GOLDEN, COLORADO

\section{ABSTRACT}

The technique of measurement uncertainty analysis as described in the current ANSI/ASME standard is applied to the testing of desiccant materials in SERI's Sorption Test Facility. This paper estimates the elemental precision and systematic errors in these tests and propagates them separately to obtain the resulting uncertainty of the test parameters, including relative humidity $( \pm .03)$ and sorption capacity $( \pm .002 \mathrm{~g} / \mathrm{g})$. Errors generated by instrument calibration, data acquisition, and data reduction are considered. Measurement parameters that would improve the uncertainty of the results are identified. Using the uncertainty in the moisture capacity of a desiccant, the design engineer can estimate the uncertainty in performance of a dehumidifier for desiccant cooling systems with confidence.

\section{NOMENCLATURE}

$\mathrm{Bi}$

B.

$\mathrm{Bw}$

BR H

mc

md , d

md , w
Elemental bias limit or systematic error

Bias limit or systematic error for a particular measurement

Total bias limit or systematic error of sorption capacity

Total bias limit or systematic error of relative humidity

Mass of empty cartridge (g)

Mass of dry desiccant, including any substrate $(g)$

Mass of desiccant after adsorption (incl. water) ( $g$ )

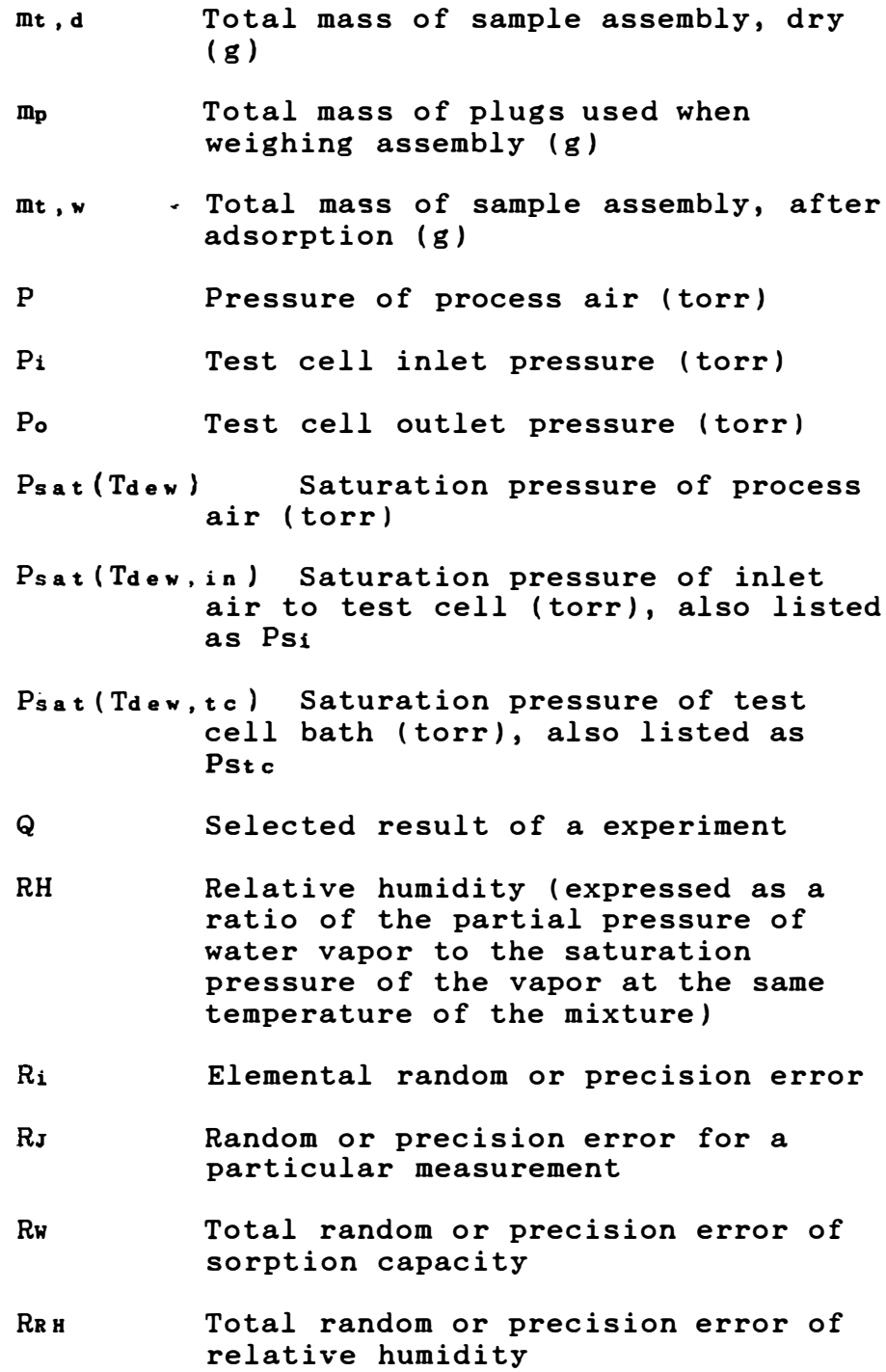




$\begin{array}{ll}\text { Tdp } & \begin{array}{l}\text { Dew point temperature (deg C), also } \\ \text { referred to as Tdew }\end{array} \\ \text { Ttc } & \text { Test cell bath temp (deg C) } \\ \text { UADD } & \begin{array}{l}\text { Total uncertainty of result by } \\ \text { additive method (Ug ) }\end{array}\end{array}$

URSs Total uncertainty of result by rootsum-square method (U95)

W

Equilibrium sorption capacity of desiccant, (g/g dry desiccant)

\section{BACKGROUND}

Desiccant cooling can be an attractive alternative to conventional vapor compression air-conditioning systems, particularly in areas with high latent loads, because of its efficiency in removing latent heat and the capability of using lower grade energy, such as solar or waste heat. The performance of desiccant dehumidifiers depends on the desiccant material used, the geometry of the humidifier and the operating conditions [Maclaine-cross and Pesaran (1986)]. The testing of adsorptive properties of desiccant materials and geometries allows the optimum selection of a combination of materials and configurations of desiccant dehumidifiers. particular interest is the sorption isotherm of a desiccant, which is the amount of moisture sorbed per unit weight of desiccant at various relative humidities, at a given temperature. The design engineer needs to know the uncertainty of the isotherm measurements to estimate the uncertainty in dehumidifier performance.

The area of measurement uncertainty has been of growing interest in recent years. The classic work on uncertainty is described in $\mathrm{Kline}$ and $\mathrm{McCl}$ intock (1953). The development of the current ASME standard is chronicled in Abernethy and Ringhiser (1985). This method involves the separate propagation of the bias error limit and the random error from the measurement process to the final test result. These separate error components are then combined by either adding or root-sum-squaring the individual components. A thorough application of this method to heat exchanger testing is contained in Farrington and Wells $(1986)$.

\section{DESCRIPTION OF THE MEASUREMENT PROCESS}

The Sorption Test Facility in the Desiccant Cooling Laboratory at SERI is used to measure the water equilibrium capacity and mass transfer rate of solid desiccant materials in different geometries under isothermal conditions. Test cells containing these materials are exposed to an adsorbing or desorbing air flow. Test cells may simulate a particular geometry, such as a packed bed or a parallel plate. Details of the test apparatus are contained in Pesaran, Parsons, and Dukehart (1986).
Dry air ( $<3$ ppm water content and $<10$ ppm other impurities) enters a mass flow controller (Tylan, model FC-260) that controls and measures the mass flow rate. The air then flows through a humidifier to obtain the desired level of water vapor concentration in the process airstream (See figure 1). In the humidifier, the dry air bubbles through deionized water in a bubbler immersed in an isothermal bath. The saturated air then passes through a chilled-mirror-type hygrometer (General Eastern model 1100DP) which measures the dew point temperature. A pressure transducer (MKS model 221) monitors the absolute pressure at this point. Next, the saturated air flows through the test cell, which is immersed in a constant-temperature deionized water bath. The test cell contains a sample of the desiccant to be tested. The test cell may be isolated from the process air by two three-way valves. The process air leaving the test cell flows through another dew point hygrometer and pressure transducer, which monitor the outlet dew point and pressure. The air is finally exhausted into the atmosphere.

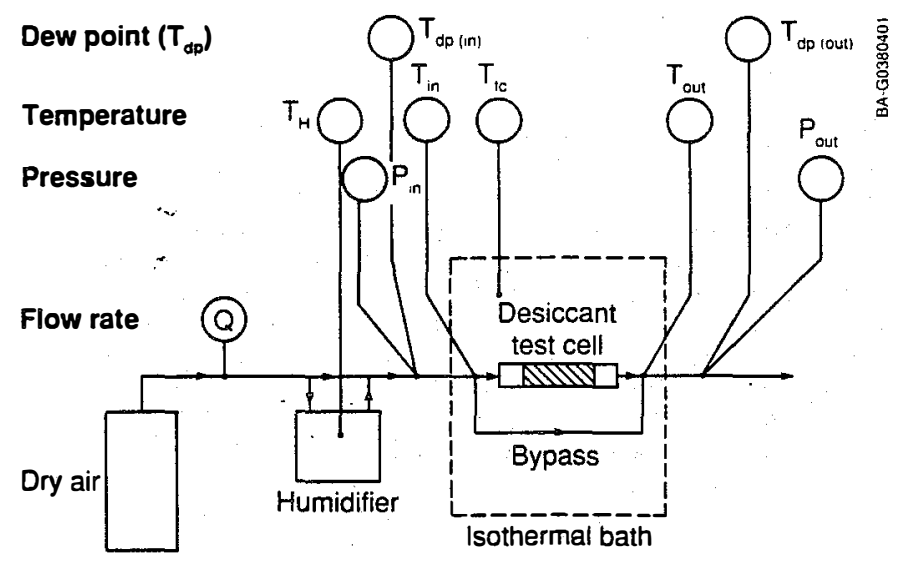

Fig. 1 Schematic of Sorption Test Facility

The packed bed test cell is a $65 \mathrm{~mm}$ long stainless steel tube having a $6.35 \mathrm{~mm}$ inside diameter and weighing approximately $65 \mathrm{~g}$. A column of desiccant particles $(0.2-1 \mathrm{~g})$ is contained between two $0.5-7$ micron sintered filter plugs. A stainless steel housing holds the test cell (the tube) in the isothermal bath. When not in the bath, vinyl plugs are used to seal the test cell, preventing the desiccant from interacting with the ambient air.

The parallel passage test cell is a $100 \mathrm{~mm}$ long aluminum cylinder with a rectangular cross section (interior dimensions $20.98 \mathrm{~mm} x$ $3.36 \mathrm{~mm})$. The desiccant is either applied to a tape, or in this case formed into a sheet $1.00 \mathrm{~mm}$ thick and that is held by a special mechanism inside the test cell, allowing an air gap of $1.18 \mathrm{~mm}$ on each side of the sheet. The test cell weighs about $51 \mathrm{~g}$ and can contain 0.2 - $2 \mathrm{~g}$ of desiccant, depending on the thickness of the desiccant. An aluminum housing holds the test cell in the isothermal bath. Teflon plugs are used to seal the test cell while out of the bath. 


\section{EXPERIMENTAL PROCEDURE}

The dry test cell is weighed, (mc), to $0.1 \mathrm{mg}$ using a Mettler model H315 precision balance. Also weighed are the plugs $\left(m_{p}\right)$ which keep the desiccant in the test cell from interacting with the ambient air during weighing. The desiccant is placed into the test cell and dried by passing dry air at 100-120 deg $C$ and ambient pressure through the sample for at least $24 \mathrm{hrs}$. The test cell is then weighed ( $m$ t, d) to determine the dry weight of the desiccant (md,d), which includes any substrate, if used. A minimum of 24 weights are averaged, re-zeroing the scale after every six weighings, to minimize the random and bias error, respectively, of all dry weights (mc, $\mathrm{m}_{\mathrm{p}}, \mathrm{mt}_{\mathrm{t}} \mathrm{d}$, and $\mathrm{md}, \mathrm{d}$ ).

After determining the dry weights, the test cell is inserted into the housing and immersed in the isothermal bath. The process air, which bypasses the test cell at this point, is conditioned to the desired humidity and pressure. Once the process air reaches equilibrium at the desired conditions, which may take from three to eight hours, the air is switched to the test cell. When the air and the desiccant reach equilibrium with each other (i.e., when the inlet and outlet air humidity ratios are the same), the housing containing the test cell is removed and is capped on both ends to prevent interaction with the ambient air. Then the test cell weighed $(m t, w)$ to determine any weight change in the desiccant resulting from moisture adsorption or desorption. The test cell is weighed ten times and averaged, re-zeroing the scale after five weighings.

The test cell is then reinstalled into the housing, immersed in the bath and exposed to the identical air conditions again. After a minimum of three hours, the sample is removed for weighing again. This procedure is repeated until the difference between. consecutive average weights $(\mathrm{mt}, \mathrm{w})$ is less than $0.2 \mathrm{mg}$. This gives a measurement of the equilibrium capacity of the desiccant at a desired humidity. Measuring effluent water vapor concentration from the desiccant as a function of time also provides data for the mass transfer rate.

The equilibrium sorption capacity of the desiccant is determined from the weight of the sample as follows:

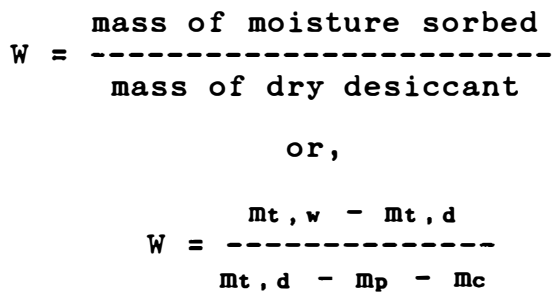

where

$$
\begin{aligned}
& m_{t, d}=m_{c}+m_{p}+m_{d, d} \\
& m_{t, w}=m_{c}+m_{p}+m_{d, w}
\end{aligned}
$$

The relative humidity, $\mathrm{RH}$, of the airstream is a ratio of the partial pressure of the vapor to the saturation pressure of the vapor at the same temperature as the mixture. It is determined from the measured dew point temperature, test cell bath temperature, and inlet and outlet air pressures as follows:

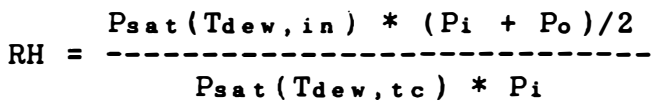

where the corrections for the real gas behavior of water vapor for inlet and test cell positions are assumed to be the same. In this paper, relative humidity will be expressed as a ratio of partial pressures, and not a percent, in order to reduce confusion with percent error.

Several measurements at the same test cell temperature and various relative humidities enable us to construct the equilibrium isotherms (i.e., $W$ vs. $R H$ at a given temperature), which can be used by others.

\section{UNCERTAINTY ANALYSIS}

The first step in the uncertainty analysis as defined in ASME/ANSI PTC 19.1-1985

"Measurement Uncertainty" (1986) is to compile a list of sources of elemental errors, typically separated into the following groups: calibration, data acquisition and data reduction. Table 1 lists estimates for the sources of elemental error for the

\begin{tabular}{|c|c|c|}
\hline owree & Bias himit & In Ercor \\
\hline $\begin{array}{l}\text { Calibration } \\
\text { Scale calibration } \\
\text { Dew point hygrometer } \\
\text { Pressure transducer } \\
\text { Test cell bath } \\
\text { thermocouple } \\
\text { Voltmeter - } \\
\text { voltage scale } \\
\text { thermal EMF }\end{array}$ & $\begin{array}{l} \pm 0.1 \mathrm{mg} \\
\pm 0.3 \mathrm{deg} C \\
\pm 0.01 \text { torr } \\
\pm 0.2 \mathrm{deg} C \\
\pm 0.1 \mathrm{mV} \\
\pm 0.0125 \mathrm{deg} C\end{array}$ & $\begin{array}{l} \pm 0.1 \mathrm{mg} \\
\pm 0.01 \mathrm{deg} C \\
\pm 0.001 \mathrm{torr} \\
\pm 0.001 \mathrm{deg} C \\
\pm 0.01 \mu \mathrm{V} \\
C \pm .0038 \mathrm{degC}\end{array}$ \\
\hline $\begin{array}{l}\text { Data Acquisition } \\
\text { Scale zero } \\
\text { Weight of sample } \\
\text { Dew point hygrometer } \\
\text { Pressure transducer } \\
\text { Test cell bath temp } \\
\text { Voltmeter - } \\
\text { voltage scale } \\
\text { reference thermo- } \\
\text { couple junction }\end{array}$ & $\begin{array}{l} \pm 0.1 \mathrm{mg} \\
\pm 0.1 \mathrm{mg} \\
\pm 0.1 \mathrm{deg} C \\
\pm 0.1 \text { torr } \\
\pm 0.2 \mathrm{deg} C \\
\pm 0.3 \mathrm{mV} \\
\pm 0.1 \mathrm{deg} C\end{array}$ & $\begin{array}{l}0 \\
\pm 0.2 \mathrm{mg} \\
\pm 0.01 \mathrm{deg} C \\
\pm 0.02 \text { torr } \\
\pm 0.02 \mathrm{deg} C \\
\pm 0.2 \mathrm{mV} \\
0\end{array}$ \\
\hline $\begin{array}{l}\text { Rata Reduction } \\
\text { Avg. sample weight } \\
\text { Saturation pressure } \\
\text { Press. non-linearity } \\
\text { Digital voltmeter } \\
\text { Thermocouple curve }\end{array}$ & $\begin{array}{l} \pm 0.1 \mathrm{mg} \\
\pm 0.01 \text { torr } \\
\pm 0.5 \text { torr } \\
\pm 0.001 \mathrm{mV} \\
\pm 0.005 \mathrm{deg} \mathrm{C}\end{array}$ & $\begin{array}{l}0 \\
\pm 0.01 \text { torr } \\
\pm 0.001 \text { torr } \\
\pm 0.001 \text { mV } \\
\pm 0.001 \text { degC }\end{array}$ \\
\hline
\end{tabular}
measurements necessary to determine the

Table 1 Estimates of Elemental Error 
sorption capacity and the relative humidity of the airstream. The errors are grouped also into two categories, random errors, which often follow a statistical distribution, and bias limits, which do not fluctuate in a random fashion. By separating these types of errors we may propagate them separately to the final result (relative humidity and sorption capacity. I

The estimates for the random errors in the weight of the sample are from several weighings where 30 or more weights were taken. These include weights of the dry cartridge, which does not include the desiccant. Since the dry weight is often weighed up to two weeks prior to the test, it is important to estimate any possible drift. The estimate of bias error comes from daily weighings of $1 \mathrm{~g}$ and $10 \mathrm{~g}$ weights, taking the difference of the two weights for several weeks, in order to determine the long-term bias or drift of the scale. No such drift was detected (the differences were random and within the $\pm 0.2 \mathrm{mg}$ random error measured above). Estimates for dew point, pressure, and thermocouple error are based on calibration data and the experience of multiple measurements.

The next step is to combine the random and bias errors separately into a total bias error limit $B_{J}$, and a total random error $R_{J}$ for each particular measurement, by root-sum-squaring the individual bias limits and random errors:

$$
\begin{aligned}
& B_{J}=\left[\Sigma\left(B_{i}\right)^{2}\right]^{1 / 2} \\
& R_{J}=\left[\Sigma\left(R_{i}\right)^{2}\right]^{1 / 2}
\end{aligned}
$$

Table 2 lists the resulting bias limits and random errors for the individual measurements.

Table_2 Bias Limits and Random Errors for Indiyidual sorption Measurements

Messurement
Bias Limit Random Error
Mass of sample, wet, mt,w $\pm 0.20 \mathrm{mg} \pm 0.22 \mathrm{mg}$
Mass of sample, dry, mt, $\pm 0.20 \mathrm{mg} \pm 0.22 \mathrm{mg}$
Mass of cartridge, mc $10.20 \mathrm{mg} \pm 0.22 \mathrm{mg}$
Mass of plug, mp.

Test cell inlet press, $\mathrm{P}_{\mathbf{i}} \pm 0.51$ tor \pm 0.03 torr Test cell outlet press,Po \pm 0.51 torr \pm 0.03 torr Inlet air sat press,

Psat (Tdew, in)

Test cell sat press,

Psat (Tdew, tc)

\pm 0.66 torr \pm 0.05 torr

\pm 0.40 torr \pm 0.02 torr

Test cell bath temp, $T_{t} c \pm 0.30$ degC \pm 0.02 degC Dew point, Tdp $\pm 0.32 \operatorname{deg} \mathrm{C} \pm 0.01 \mathrm{deg} C$

The next step is to apply sensitivity factors to the measurements by either a computer perturbation of each measurement parameter, or taking the partial differentials of the governing equations with respect to each measurement. In general, the total bias limit and random error of quantity $Q$ caused by measurement $J$ are:

$$
\begin{array}{ll}
B_{Q}=(\Sigma(\delta Q / \delta J \cdot & \left.B J)^{2}\right)^{1 / 2} \\
R_{Q}=(\Sigma(\delta Q / \delta J \cdot & \left.R J)^{2}\right)^{1 / 2}
\end{array}
$$

For example, in our case the total bias error for the sorption capacity $W$ is

$$
\begin{aligned}
& \left.B_{W}=\left[\frac{\delta W}{\delta m t, w} t_{t, w}\right)^{2}+\underset{\delta m t, d}{\left(-\frac{\delta W}{\delta m} B_{t, d}\right.}\right)^{2} \\
& \left.\left.+\underset{\delta m_{c}}{\left(\frac{\delta W}{c-} B_{n}\right)^{2}}+\underset{\delta m_{p}}{\left(---B_{p}\right.}\right)^{2}\right]^{1 / 2}
\end{aligned}
$$

or,

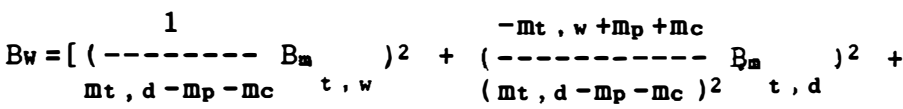

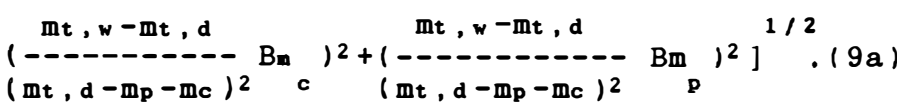

For the relative humidity we have

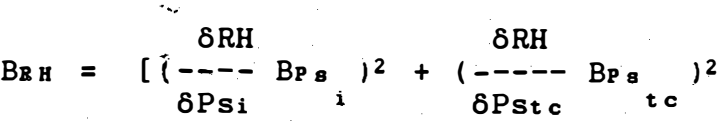

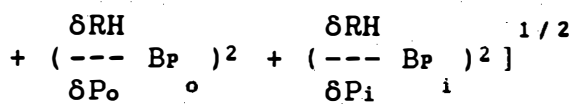

where Psi $=$ Psat $\left(T_{d e w, i n)}\right.$ and Pstc $=$ Psat $\left(T_{d e} w, t c\right)$

which comes out to be

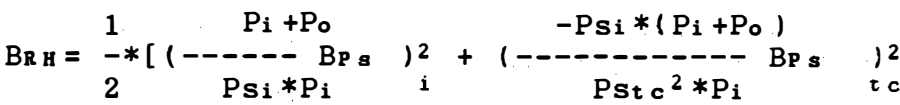

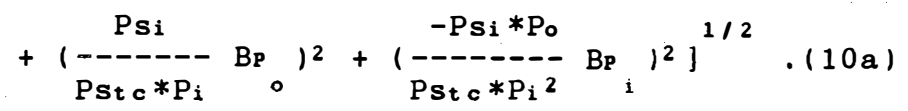

Using the nominal values in Table 3 (which are for a test using Syloid 63 in the packed bed test cell), we can then obtain the total bias and random error for the sorption capacity and the relative humidity.

The results of these calculations are portrayed in Table 4. The errors in relative humidity are in units of the pressure ratio, e.g., a \pm 0.025 bias error limit represents a relative uncertainty of $\pm 4.7 \%$ of a nominal relative humidity of 0.539 .

The final step in the analysis is to combine the random and systematic or bias errors into a total uncertainty, applying a statistical 
Table 3 Nominal Values of Measurements

Mass of sample, wet, mt,w

$63.9277 \mathrm{~g}$

$63.7557 \mathrm{~g}$

$58.7200 \mathrm{~g}$

$4.4042 \mathrm{~g}$

Mass of empty cartridge, mo

Mass of plug, mp

Mass of dry desiccant, md, d

$0.6315 \mathrm{~g}$

Test cell inlet pressure, $\mathrm{P}_{\mathrm{i}}$

Test cell outlet pressure, Po

781.3 torr

767.5 torr

Inlet air sat. press,Psat (Tdew,in) 17.325 torr

Test cell sat. press,Psat (Tdew,tc) 31.846 torr

Relative humidity, $\mathrm{RH}$

0.539

Water adsorbed, $W$

0.272

$\mathrm{kg} / \mathrm{kg}$ dry desiccant

Test cell bath temp, Ttc

30 deg $\mathrm{C}$

Inlet dew point, Tdp

Table 4 Bias Limit and Random Error of

Sorption Capacity and Humidity

\begin{tabular}{llll} 
& $\begin{array}{l}\text { Nominal } \\
\text { Value }\end{array}$ & $\begin{array}{l}\text { Bias } \\
\text { Limit }\end{array}$ & $\begin{array}{l}\text { Random } \\
\text { Error }\end{array}$ \\
\hline Relative humidity & 0.539 & \pm 0.025 & \pm 0.001 \\
Sorption capacity & $0.272 \mathrm{~g} / \mathrm{g} \pm .00053$ & \pm .00059
\end{tabular}

distribution to the random component. This can be done in either of two methods, additive or root-sum-square. The additive model simply adds the bias component to the product of the random component and statistical distribution, i.e.,

$$
U_{A D D}= \pm(B T+t R T)
$$

where $t$ is from the two-tailed student's " $t$ " table (found in the ANSI/ASME standard (1986), or any statistics textbook), which accounts for the sample size; we used a value of 1.96 , which assumes a sample size greater than 30 . The additive model accounts for about $99 \%$ of variation of the final result.

The root-sum-square model is applied as follows :

$$
U_{R S S}= \pm\left[\left(B_{T}\right)^{2}+\left(t R_{T}\right)^{2}\right]^{1 / 2}
$$

The root-sum-square model accounts for approximately $95 \%$ of variation. The final uncertainties are contained within Table 5 . As before, the uncertainties for relative humidity are absolute values, and not a percentage of the nominal value.

Table 5 Total Uncertainty of Sorption and Humidity

\begin{tabular}{llll} 
& $\begin{array}{l}\text { Nominal } \\
\text { Value }\end{array}$ & UAD & URs.s \\
\hline Relative humidity & 0.539 & \pm 0.028 & \pm 0.026 \\
Sorption capacity & 0.272 & \pm 0.002 & \pm 0.001
\end{tabular}

RESULTS

Several interesting results become evident from the sensitivity analysis, for example, the nominal case of Syloid 63 at 0.539 relative humidity. For instance, $a+1 \operatorname{deg} C$ error in the measurement of the test cell bath or the dew point of the inlet air stream results in a -0.030 or +0.034 error in the relative humidity, respectively. However, an error of +1 torr in the inlet or outlet pressure results in only a -0.0003 error in the relative humidity. Therefore, our interest in improving the relative humidity measurement should center around the bath temperature and dew point measurements, and not the pressure measurement.

Another way to examine the elemental errors and their effect on the final result is to reexamine Table 1 and express the uncertainties in units of the final answer. Tables 6 and 7 do just that. All the elemental errors are listed, along with the portion of the final uncertainty they represent, expressed in the final units.

Table 6 Elemental Errors contributing to Relative Humidity Uncertainty

\begin{tabular}{lrr} 
Source & $\begin{array}{c}\text { Error in RH } \\
\text { Bias }\end{array}$ & $\begin{array}{c}\text { (ratio) } \\
\text { Randem }\end{array}$ \\
\hline Calibration & 0.0121 & 0.0004 \\
$\begin{array}{l}\text { Dew point hygrometer } \\
\text { Pressure transducer }\end{array}$ & $<0.0001$ & $<0.0001$ \\
Test cell bath & & \\
$\quad$ thermocouple & 0.0011 & $<0.0001$ \\
Voltmeter - & $<0.0001$ & 0. \\
$\quad$ voltage scale & $<0.0001$ & $<0.0001$ \\
thermal EMF & & \\
Data Acquisition & 0.0010 & 0.0004 \\
$\begin{array}{l}\text { Dew point hygrometer } \\
\text { Pressure transducer }\end{array}$ & $<0.0001$ & $<0.0001$ \\
Test cell bath temp & 0.0011 & 0.0004 \\
Voltmeter - & & \\
$\quad$ voltage scale & $<0.0001$ & $<0.0001$ \\
$\quad$ ref TC junction & 0.0002 & 0. \\
Rata Reduction & & \\
Saturation pressure & $<0.0001$ & $<0.0001$ \\
Press non-linearity & $<0.0001$ & $<0.0001$ \\
Digital voltmeter & $<0.0001$ & $<0.0001$ \\
Thermocouple curve & $<0.0001$ & $<0.0001$ \\
\end{tabular}

Table 7 Elemental Errors Contributing to Equilibrium Sorption Capacity Uncertainty

\begin{tabular}{lcl} 
Source & Error in capacity $(g / g)$ \\
\hline Scale calibration & 0.0001 & 0.0001 \\
Scale zero & 0.0001 & 0. \\
Weight of sample & 0.0001 & 0.0001 \\
Avg. sample weight & 0.0001 & 0.
\end{tabular}

The sum of the errors is less than the total uncertainty since the total is the result of a root-sum-square process. Nonetheless, the relative value of these elemental errors tells 
us which to focus on in order to reduce the uncertainty of the test. By far the most significant is the accuracy of the dew point hygrometer.

In order to see how the uncertainty analysis affects the actual results of the sorption testing, two materials have been selected that represent different adsorption capabilities. The first, Syloid 63, has an adsorption capacity similar to microporous silica gel and was tested in the packed bed test cell. The second material, which is a composite material of silica gel mixed with Devcon epoxy. The Devcon composite was tested in the parallel passage test cell, and showed a lower capacity for adsorption. The lower capacity was due to the blockage of silica gel pores with epoxy, making adsorption ineffective. This gives us a range of adsorption capacities for the test apparatus.

The nominal values used in the uncertainty analysis above represent tests of syloid 63. The test results for Syloid 63 , a synthetic amorphous silica with an average particle size of 9 microns, are shown in Figure 2. Shown is the sorption capacity in $g$ moisture / g dry desiccant vs. the relative humidity: From our uncertainty analysis above, we see that at 0.54 relative humidity, the error in the sorption capacity is $\pm 0.002 \mathrm{~g} / \mathrm{g}$ out of 0.272 $\mathrm{g} / \mathrm{g}$, or $\pm 0.6 \%$. The error in the relative humidity, however is more significant, \pm 0.028 out of 0.54 , or $\pm 5.2 \%$ of the nominal value.

Low and high points on the graph were analyzed to determine any change in uncertainty. At a relative humidity of 0.16 , the uncertainty of the $R H$ was also $\pm 0.028( \pm 17.5 \%)$, and the uncertainty of the sorption capacity was again about \pm 0.002 , which out of $0.104 \mathrm{~g} / \mathrm{g}$, represents a higher $\pm 1.4 \%$. At the higher point, $0.74 \mathrm{RH}$, the relative humidity was \pm 0.029 (which represents $3.9 \%$ of the nominal value) while the uncertainty of the sorption capacity was about \pm 0.002 out of $0.308 \mathrm{~g} / \mathrm{g}$, or

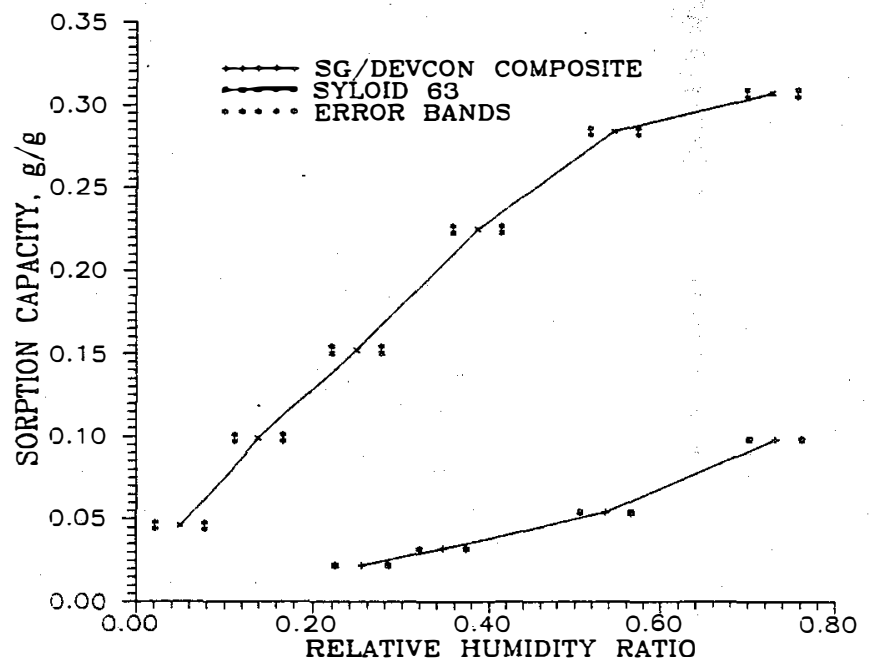

Fig. 2 Uncertainties of Adsorption Capacity and Humidity of Two Desiccants $\pm 0.6 \%$. Therefore, no variation in uncertainty was found as a function of humidity. The results are portrayed in Table 8 .

For the Silica Gel/Devcon composite, tested in the parallel passage test cell, several of the weights were slightly different than those used for Syloid 63, primarily because of the use of the different test cell. The cartridge weight, mc, was $50.4206 \mathrm{~g}$, the plug weight, $\mathrm{m}_{\mathrm{p}}, 9.7259 \mathrm{~g}$, and the dry desiccant weight, mdd, $1.8178 \mathrm{~g}$. As can be seen from Table 8, the uncertainty of the relative humidity is quite similar to that of the syloid 63 tests.

However, the absolute uncertainty of the capacities of the Devcon composite is less than one-third of the Syloid 63. This is likely because the dry desiccant, the denominator in the capacity calculation, is three times larger for the Devcon $(1.8178 \mathrm{~g}$ of dry desiccant vs $0.6316 \mathrm{~g}$ for the Syloid 63 .) However, for the Devcon, which has a much lower capacity, this represents a higher percentage error, $\pm 2.2 \%$ for the $0.023 \mathrm{~g} / \mathrm{g}$ data point and $\pm 0.6 \%$ for the $0.098 \mathrm{~g} / \mathrm{g}$ point. Comparing this to the Syloid 63 low humidity test, which has a similar adsorption capacity $(0.014$ vs. $0.098 \mathrm{~g} / \mathrm{g})$, we see that the $\pm 0.6 \%$ error in capacity compares to the $\pm 1.4 \%$ for the Syloid 63 at a similar capacity. Thus it appears that the relative uncertainty gets larger at lower capacities, and is not necessarily related to the dry weight of the sample.

Table 8 Uncertainty for Typical Tests - Syloid 63 and Silica Gel Leveon composite

$\begin{array}{llll}\text { Lest and result } & \begin{array}{l}\text { Nominal } \\ \text { Value }\end{array} & \text { Uard } & \text { URs } \\ \text { Syloid } 63- & & & \\ \text { low humidity } & & \pm 0.028 & \pm 0.026 \\ \text { Relative humidity } & 0.160 & \pm 0.002 & \pm 0.001\end{array}$

Sorption capacity $0.104 \mathrm{~g} / \mathrm{g} \pm 0.002 \pm 0.001$

Syloid 63 -

high humidity

Relative humidity $0.740 \quad \pm 0.029 \pm 0.027$

Sorption capacity $0.308 \mathrm{~g} / \mathrm{g} \quad \pm 0.002 \pm 0.001$

Silica Gel/Devcon -

low humidity

Relative humidity $0.254 \quad \pm 0.028 \pm 0.026$

Sorption capacity $0.023 \mathrm{~g} / \mathrm{g} \pm 0.0005 \pm 0.0004$

Silica Gel/Devcon -

high humidity

Relative humidity $0.732 \quad \pm 0.030 \pm 0.027$

Sorption capacity $0.098 \mathrm{~g} / \mathrm{g} \quad \pm 0.0005 \pm 0.0004$

\section{CONCLUSIONS AND RECOMMENDATIONS}

It is obvious from this analysis that we have measured the sorption capacity with much better accuracy than the relative humidity. The uncertainty in the capacity is \pm 0.0005 to \pm 0.002 for nominal values of $0.023 \mathrm{~g} / \mathrm{g}$ to $0.308 \mathrm{~g} / \mathrm{g}$, which represents a relative 
uncertainty of $\pm 0.6 \%$ to $\pm 2.2 \%$, respectively. The uncertainty of the relative humidity is \pm 0.026 to \pm 0.030 for nominal values of 0.160 to 0.740 , representing a relative uncertainty of $3.9 \%$ for the higher humidities and $17.5 \%$ at the lower humidities. This is primarily due to increased precision and reduced bias in the scale than in the dew point hygrometer and thermocouple.

The error band for the relative humidity is essentially the same at both low and high values of humidity, although this results in larger relative variations at lower values. Similarly, the absolute value of the error in sorption capacity remains relatively constant at both high and low values, resulting in a higher percentage error in the lower range (up to $\pm 2.2 \%$ ), as compared to the higher range (up to $\pm 0.6 \%)$.

There appears to be little value in improving our weight measurements. Our humidity measurements could be improved, either by improving our measurement of the dew point of the inlet air stream or the test cell bath temperature. Our sensitivity analysis indicated that the inlet and outlet pressure measurements are not significant contributors to the error.

However, if we were able to reduce the bias errors of the test cell bath temperature measurement by $50 \%$ ( from \pm 0.2 deg $C$ to \pm 0.1 deg $C$ ), the uncertainty in the relative humidity in the nominal case (using the additive method) would drop from \pm 0.028 to \pm 0.026 . Similarly, if the hygrometer had an accuracy of \pm 0.1 deg $C$ instead of $\pm 0.3 \mathrm{deg} C$, the uncertainty would drop from \pm 0.028 to \pm 0.018 . Both improvements would result in a reduction in uncertainty of \pm 0.028 to \pm 0.015 . This must be weighed against the cost and availability of instruments of such precision. These data are going to be used for evaluation of the potential of various desiccant

materials for desiccant cooling systems as well as for system simulations. The uncertainty of the measurements is quite acceptable for such calculations.

\section{ACKNOWLEDGEMENTS}

This work was funded by the U.S. Department of Energy, Office of Solar Heat Technologies. The authors wish to thank Rob Farrington and Jim Green of SERI for their assistance in applying the method and review of the results.

\section{REFERENCES}

Abernethy, R. B. and Ringhiser, B., 1985, "The History and Statistical Development of the New ASME-SAE-AIAA-ISO Measurement Uncertainty Methodology," AIAA-85-1403, Presented at the AIAA/SAE/ASME/ASEE 21st Joint Propulsion Conference, July 8-10, 1985, Monterey, California.

ANSI/ASME PTC 19.1-1985, 1986, "Measurement Uncertainty," Supplement to ASME Instruments and Apparatus Performance Test Codes, The American Society of Mechanical Engineers, New York.

Farrington, R.B., Wells, C., April 1986, " $A$ Thorough Approach to Measurement Uncertainty Analysis Applied to Immersed Heat Exchanger Testing," SERI/TP-253-2862, Solar Energy Research Institute, Golden, co.

Kline, S.J., and McClintock, F.A., 1953, "Describing Uncertainties in Single-Sample Experiments," Mechanical Engineering, Vol 75.

Maclaine-cross, I., and Pesaran, A., April 1986, "Heat and Mass Transfer Analysis of Dehumidifiers Using Adiabatic Transient Tests" SERI/TP-252-2919R, Solar Energy Research Institute, Golden, $\mathrm{CO}$.

Pesaran, A. A., Parsons, J., and Dukehart, K., December 1986, "Experiments on Desiccant Materials and Geometries for Desiccant Dehumidifiers," SERI/TR-252-3065, Solar Energy Research Institute, Golden, CO (Draft Report). 